\title{
INTRAPRENEURIAL COMPETENCIES IN FASHION COMPANY: DISTINCTIVE BETWEEN MANAGERIAL AND NON-MANAGERIAL LEVEL
}

\author{
Iman Sudirman ${ }^{1}$, Indryati Sunaryo ${ }^{2}$, Made Andriani ${ }^{3 *}$, Atya Nur Aisha ${ }^{4}$, Dwirany Dian Audy Sinaga ${ }^{5}$ \\ ${ }^{1,2,3,5}$ Department of Industrial Engineering, Bandung Institute of Technology, Bandung, Indonesia, ${ }^{4}$ Department of \\ Industrial Engineering, Telkom University, Bandung, Indonesia. \\ Email: "mdandriani@mail.ti.itb.ac.id
}

Article History: Received on $15^{\text {th }}$ September 2019, Revised on $10^{\text {th }}$ February 2020, Published on $03^{\text {rd }}$ March 2020

\begin{abstract}
Purpose of the study: Human resources are the main factor of competitive advantage in an organization, so the quality of employees becomes essential. This study aims to identify distinctive competencies for managerial and non-managerial levels in the fashion industry. Different job level needs a different level of skills and it shows the variation in training needs.
\end{abstract}

Methodology: This research was done using qualitative studies with structured literature review and semi-structured interviews with managers as a preliminary stage. The primary research was done through a survey method using questionnaires distributed to 200 employees in a fashion company.

Result: The result shows that there were nine different competencies needed by managerial and non-managerial level, namely (1) Achievement orientation, (2) Concern for order, (3) Information seeking, (4) Relationship building, (5) Developing others, (6) Teamwork, (7) Team leadership, (8) Analytical thinking, and (9) Sense of humor. Besides, it was found that both positions need Entrepreneurial thinking and Innovation management competencies at a similar level of importance. This similarity shows that all levels of employees must own the intrapreneurship spirit in the company because the product and business innovation can come from all employees.

Applications of this study: Differences in competency requirements at managerial and non-managerial levels will have an impact on variations in the needs pf employee training and development. For example, in achievement orientation competency, training for the managerial level is directed not only to meet targets but to the possibility of creating new business opportunities.

Novelty/Originality of this study: The result of the literature study shows that many previous studies have identified competency models in the creative industries. Still, only a few have identified in detail the differences in intrapreneur competency needs at managerial and non-managerial levels.

Keywords: Intrapreneurial Competencies, Competency Model, Creative Industries, Fashion Company, Managerial Level, Non-managerial Level.

\section{INTRODUCTION}

The creative industry is one sector that develops and supports economic growth in Indonesia. It is shown by the value of the contribution of the creative economy sector of 7.44\% of Indonesia's national GDP in 2016. Three subsectors dominate the creative economy in Indonesia, namely culinary, fashion, and craft. These three subsectors make the most significant contribution to GDP and the number of exports. The largest export level is produced by the fashion subsector (56\%) with various export destinations, such as the United States, Japan, Switzerland, Germany, and others. In addition, the fashion subsector also supports the growth of entrepreneurial women in Indonesia, as seen from the number of female entrepreneurs in this subsector reaching 42.83\% (Indonesian Creative Economy Agency, 2017). Therefore, the ability of human resources in the fashion industry (both from entrepreneur, managers, and workers) still need to be developed.

The creative industry is required to develop and introduce innovation as part of their primary business activities. The innovation can be in the form of product innovation or process innovation (Müller, Rammer, and Truby, 2009). In supporting this, intrapreneurship in a company becomes essential. Intrapreneurship is an initiative by employees in the organization to conduct new business activities (Bosma, Wennekers and Stam, 2010). Activities related to intrapreneurship are the perception of opportunities, generation of ideas, designing of new products or other combinations of resources, development of internal coalitions, management of persuasion, acquisition of resources, and planning and organization (Bosma, Wennekers and Stam, 2010). Thus, the development of the creative industry is hugely determined by competencies that can support intrapreneurship in carrying out its business activities.

Human resource competency is necessary for developing the organization and competency management can enhance value in human resource strategy (Dai and Liang, 2012). Several previous studies provided a general competency model for intrapreneurs (Vargas-Halabí, Mora-Esquivel, and Siles, 2017; Rathna and Vijaya, 2009). Also, there are competency models for creative professionals (Mietzner and Kamprath, 2013), competency models in the culinary industry ( $\mathrm{Hu}$, 2010), and competency models for entrepreneurs in the software industry (Aisha, Siswanto, and Sudirman, 2016). 
However, these five competency models provide a general competency model without distinguishing the needs between non-managerial and managerial positions. Thus, this study will analyze the differences in the needs of intrapreneurial competence in the fashion company, as a subsector of the creative industry, for non-managerial and managerial positions. Besides, this study also aims to identify the competency gap between the needs and existing competency. This competency gap can be used as a basis in determining the training needs for the managerial and non-managerial level.

\section{LITERATURE REVIEW}

This study begins with a literature study related to intrapreneurship, differences in intrapreneurs and entrepreneurs and competency models. Intrapreneurship is an initiative by employees in the organization to conduct new business activities. Intrapreneurship deals with individual levels and about bottom-up, namely proactive work initiatives from each employee (Bosma, Wennekers and Stam, 2010). There are several similarities between intrapreneur and entrepreneur, namely: (1) both are innovative individuals, (2) both create value or add further value, (3) both must take risks (Maier and Zenovia, 2011; Cadar and Badulescu, 2015). The differences of intrapreneurs and entrepreneurs are: (1) intrapreneur activity has the character of renewal, while entrepreneurial activity has the character of creativity, (2) in intrapreneurs, corporate culture becomes the main obstacle, while entrepreneurs have one of the main obstacles, namely the market, (3) intrapreneurs use company resources and very large, while entrepreneurs must find their funding resources that risk losing assets or wealth themselves (Bosma, Wennekers and Stam, 2010; Cadar and Badulescu, 2015).

According to Spencer and Spencer (1993), competency is a basic human characteristic that is proven empirically to influence and can be used to predict work effectiveness or superior performance in a job or a situation. There are five basic components from the competency, namely knowledge, skill, self-concept, traits, and motives. The competency component can be divided into 2, namely visible competencies and hidden competencies. Visible competencies are components of competency that can be identified and measured above the surface such as skills and knowledge. Hidden competencies are component of competency that is more difficult to detect including self-concept, motives, and traits (Spencer and Spencer, 1993; Chouhan and Srivastava, 2014). Visible competencies (such as skills and knowledge) tend to be more easily developed and trained, than hidden competencies. Therefore, in recruitment, the more reasonable thing to do is to recruit and choose based on hidden competencies rather than training people in the short term. However, for human resource development and career path planning, it can provide an opportunity to develop critical visible competencies in the future, based on more senior roles (Spencer and Spencer, 1993). The organization needs to build a competency model to manage its competencies (Siswanto, 2013).

In a job, individual competence will last, while certain work activities and work tasks are temporary. The competency model can complement traditional job descriptions and become the basis for the entire human resource management system (Dubois and Rothwell, 2004). In this research Competency models used are competency models for intrapreneurs in general (Vargas-Halabí, Mora-Esquivel, and Siles, 2017), competency models for creative professionals (Mietzner and Kamprath, 2013), competency models in the culinary industry ( $\mathrm{Hu}, 2010)$, and competency models for entrepreneurs in the software industry (Aisha, Siswanto, and Sudirman, 2016). All competency models used will be compared to produce the proposed competency models.

The first competency model is a competency model for intrapreneurs. This competency model is the main competency model needed in this study because the purpose of the research is to identify the needs of intrapreneurial competence in the creative industry for non-managerial and managerial positions. Vargas-Halabi, Mora-Esquivel, and Siles (2017)developed an intrapreneurial competency model. The study aims to develop and validate a measurement tool for intrapreneurial competence. At the conceptual level, there are seven dimensions of competence, namely exploiter of opportunities, pro-innovator, idea stimulator, planner, resource manager, support network builder, and builder of interactions with others. Based on the results of factor analysis, there were five intrapreneurial competency factors, namely opportunity promoter, proactivity, flexibility, drive, and risk-taking. These five factors produce a questionnaire consisting of 20 statement items that describe a competency unit.

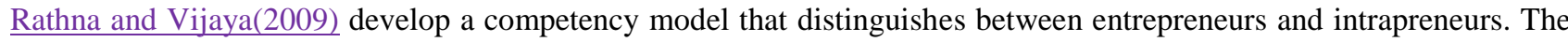
study was conducted using a questionnaire and distributed in a sample of 30 entrepreneurs and 30 intrapreneurs. The results obtained are six competency clusters owned by an intrapreneur namely managerial behavior competencies, interpersonal behavior competencies, decisive behavior competencies, ethical orientation competencies, enterprising behavior competencies, and learning orientation competencies. Each cluster consists of several statement items that are used to measure competency units.

The next competency model is the competency model for creative professionals by Mietzner and Kamprath (2013). The study aims to identify which competencies must be considered for curriculum development and study programs in creative professional education. The results obtained are there are three competency groups, namely personal-social consisting of 17 competency units, methodological consisting of 9 competency units, and professionals consisting of 10 competency units.

This study also used the competency model for the culinary industry from $\underline{\mathrm{Hu}(2010)}$, because it is one of the sub-sectors of the creative industry. Hu's (2010) research aims to identify the core competencies of innovative culinary development (ICD) using in-depth interviews, the Delphi method, and the analytic network process (ANP). From the interview, the 
list of competencies in the culinary industry consisted of 156 competency units is resulted. A final of 31 ICD core competencies that classify to seven dimensions was found from Delphi and ANP methods. These details of core competencies are each five competencies from the innovative product, management, and creativity dimensions, as well as every four competencies from culture, service, aesthetics, and technology dimensions.

The next competency model is the competency model for entrepreneurs in the software industry from Aisha, Siswanto, and Sudirman (2016). This competency model was used to obtain input on the competencies needed by entrepreneurs. Because there are still some similarities between entrepreneurs and intrapreneurs, so there is still a possibility of similarities in competency needs. This research starts by conducting a comprehensive literature review of the competency model - next, an in-depth interview with several entrepreneurs in the industry for model validation. The results of the study show that there are three competency groups, namely entrepreneurial competencies include six competency units, managerial competencies consist of six competency units, while the industrial context competencies include five competency units.

\section{METHODOLOGY}

\section{Case Description}

This study is conducted at a fashion creative industry company, identified as Company XYZ. The company was founded in 1988 in Bandung, Indonesia. Now, its headquarter is located in Jakarta, with a factory located in Bandung. The main product is casual shoes which are focused on schoolchildren's shoes. The company currently has 22 independent retail stores and 376 outlets all over Indonesia. This study was conducted at a factory located in Bandung. Thus, respondents in this study were only employees who worked in Bandung. According to the human resource data in May 2018, the company currently has 616 permanent employees working in Bandung. Specifically, there were 85 managerial-level employees and 531 non-managerial level employees.

The 616 employees in Bandung were considered as the population of the study. According to Hair et al. (2010), the number of the sample could be determined based on the number of research variables multiply by 5 . In this study, there are 38 competency units considered as research variables, so the minimum number of samples required is 190 employees. The questionnaire was distributed through the printed form to the 221 employees, with the proportion sampling between managerial-level and non-managerial level. The study conducted in May 2018, after two weeks of questionnaire distribution, 210 questionnaires were returned. The response rate is $85 \%$ from 190 usable responses. The respondents consist of 27 managerial-level employees and 163 non-managerial level employees.

\section{Research Stages}

The first stage identifies relevant intrapreneurial competencies that become the foundation of this study. In generating the competencies list, there are two stages conducted. First, create a comprehensive list of competencies from the competency model in the previous study. A comparison of competency models is carried out on the previous five competency models, namely a generic competency model for intrapreneurs (Vargas-Halabí, Mora-Esquivel, and Siles, 2017; Rathna and Vijaya, 2009). In addition, there are competency models for creative professionals (Mietzner and Kamprath, 2013), competency models in the culinary industry ( $\mathrm{Hu}, 2010)$, and competency models for entrepreneurs in the software industry (Aisha, Siswanto, and Sudirman, 2016). The comparison result of the competency models was made as illustrated in Table 1.

Table 1: Model for Paper

\begin{tabular}{|c|c|c|c|c|c|c|}
\hline \multirow{2}{*}{ Competency Unit } & \multicolumn{5}{|c|}{ Previous Research } & \multirow{2}{*}{ Competency Used } \\
\hline & [4] & [5] & {$[6]$} & [7] & {$[8]$} & \\
\hline Achievement orientation & $\mathrm{v}$ & $\mathrm{v}$ & $\mathrm{V}$ & $\mathrm{V}$ & $\mathrm{V}$ & $\mathrm{v}$ \\
\hline Concern for order & $\mathrm{V}$ & $\mathrm{V}$ & & & $\mathrm{V}$ & $\mathrm{V}$ \\
\hline Initiative & $\mathrm{V}$ & $\mathrm{v}$ & $\mathrm{V}$ & & & $\mathrm{V}$ \\
\hline Information seeking & $\mathrm{v}$ & $\mathrm{v}$ & & & & $\mathrm{v}$ \\
\hline Interpersonal understanding & & $\mathrm{V}$ & & & & $\mathrm{v}$ \\
\hline Customer service orientation & & & & $\mathrm{V}$ & $\mathrm{V}$ & $\mathrm{V}$ \\
\hline Impact and influence & $\mathrm{V}$ & $\mathrm{V}$ & & & & $\mathrm{v}$ \\
\hline Organizational awareness & & $\mathrm{v}$ & & & & $\mathrm{V}$ \\
\hline Relationship building & $\mathrm{V}$ & $\mathrm{v}$ & $\mathrm{V}$ & $\mathrm{V}$ & $\mathrm{V}$ & $\mathrm{V}$ \\
\hline Developing others & & $\mathrm{v}$ & & & & $\mathrm{V}$ \\
\hline Directiveness & & $\mathrm{v}$ & & & & $\mathrm{V}$ \\
\hline Teamwork & $\mathrm{V}$ & $\mathrm{v}$ & $\mathrm{V}$ & & & $\mathrm{V}$ \\
\hline Team leadership & & $\mathrm{v}$ & & & & $\mathrm{v}$ \\
\hline Analytical thinking & & $\mathrm{V}$ & $\mathrm{V}$ & & $\mathrm{V}$ & $\mathrm{v}$ \\
\hline Conceptual thinking & $\mathrm{v}$ & $\mathrm{v}$ & $\mathrm{V}$ & $\mathrm{V}$ & $\mathrm{V}$ & $\mathrm{V}$ \\
\hline Self-assessment & & $\mathrm{v}$ & & & & $\mathrm{V}$ \\
\hline
\end{tabular}




\begin{tabular}{|c|c|c|c|c|c|c|}
\hline \multirow{2}{*}{ Competency Unit } & \multicolumn{5}{|c|}{ Previous Research } & \multirow{2}{*}{ - Competency Used } \\
\hline & $\overline{\text { [4] }}$ & [5] & [6] & [7] & {$[8]$} & \\
\hline Writing skill & & $\mathrm{v}$ & & & & $\mathrm{v}$ \\
\hline Learning from experience & & $\mathrm{v}$ & & & & $\mathrm{v}$ \\
\hline Self-confidence & $\mathrm{v}$ & $\mathrm{v}$ & $\mathrm{v}$ & & $\mathrm{v}$ & $\mathrm{v}$ \\
\hline Flexibility & $\mathrm{v}$ & $\mathrm{v}$ & $\mathrm{v}$ & $\mathrm{v}$ & & $\mathrm{v}$ \\
\hline Organizational Commitment & & $\mathrm{v}$ & $\mathrm{v}$ & & $\mathrm{v}$ & $\mathrm{v}$ \\
\hline Low fear of rejection & $\mathrm{v}$ & $\mathrm{v}$ & & & & $\mathrm{v}$ \\
\hline Learning orientation & & $\mathrm{v}$ & $\mathrm{v}$ & & $\mathrm{v}$ & $\mathrm{v}$ \\
\hline Sense of humor & & $\mathrm{v}$ & & & & $\mathrm{v}$ \\
\hline The sensibility of fashion trend & & & & $\mathrm{v}$ & & $\mathrm{v}$ \\
\hline Sensibility of aesthetics & & & & $\mathrm{v}$ & & $\mathrm{v}$ \\
\hline Risk management & $\mathrm{v}$ & $\mathrm{v}$ & & & $\mathrm{v}$ & $\mathrm{v}$ \\
\hline Business functional & & & $\mathrm{v}$ & & $\mathrm{v}$ & $\mathrm{v}$ \\
\hline Innovation management & & & $\mathrm{v}$ & $\mathrm{v}$ & & $\mathrm{v}$ \\
\hline Change management & & & $\mathrm{v}$ & $\mathrm{v}$ & & $\mathrm{v}$ \\
\hline Legislation/law/IP and copyrights & & & $\mathrm{v}$ & & & $\mathrm{v}$ \\
\hline Sector-crossing competence & & & $\mathrm{v}$ & & & $\mathrm{v}$ \\
\hline Entrepreneurial thinking & $\mathrm{v}$ & $\mathrm{v}$ & $\mathrm{v}$ & & & $\mathrm{v}$ \\
\hline Project management & $\mathrm{v}$ & $\mathrm{v}$ & $\mathrm{v}$ & & $\mathrm{v}$ & $\mathrm{v}$ \\
\hline Technology trend analysis & & & $\mathrm{v}$ & $\mathrm{v}$ & $\mathrm{v}$ & $\mathrm{v}$ \\
\hline Product knowledge & & & & $\mathrm{v}$ & $\mathrm{v}$ & $\mathrm{v}$ \\
\hline Knowledge of Present Culture & & & & $\mathrm{v}$ & & $\mathrm{v}$ \\
\hline Intercultural Understanding & & & $\mathrm{v}$ & $\mathrm{v}$ & & $\mathrm{v}$ \\
\hline Software Development Cycle & & & & & $\mathrm{v}$ & \\
\hline Programming Language & & & & & $\mathrm{v}$ & \\
\hline Software Development Tools & & & & & $\mathrm{v}$ & \\
\hline Ability to Assess & & & $\mathrm{v}$ & & & \\
\hline Analysis of Understanding & & & $\mathrm{v}$ & & & \\
\hline Knowledge of Products with Harmony Flavor & & & & $\mathrm{v}$ & & \\
\hline Knowledge of Matching Cuisine and Unique Utensil & & & & $\mathrm{v}$ & & \\
\hline Knowledge of Using New and Unique Ingredients & & & & $\mathrm{v}$ & & \\
\hline Knowledge of Designing Unique Dine Experience & & & & $\mathrm{v}$ & & \\
\hline Ability to Deliver Cuisine Story during Service & & & & $\mathrm{v}$ & & \\
\hline Ability to Develop New Culinary Service & & & & $\mathrm{v}$ & & \\
\hline Positive attitude toward Add New Value during Service Delivery & & & & $\mathrm{v}$ & & \\
\hline
\end{tabular}

From the comparisons in Table 1, several competencies are not used in this study, namely software development cycles, programming languages, and software development tools because those competencies are specific to the software industry; ability to assess and analysis understanding because in the comparison process with other literature there is no apparent purpose of the two competencies; as well as knowledge of products with harmony flavor, cuisine and unique utensil knowledge of matching, knowledge of using new and unique ingredients, unique knowledge of designing dine experience, story to service's ability to deliver, ability to develop new culinary service, and positive attitude toward adding new value during service delivery, because those competencies are specific for the culinary industry. After the elimination, it results in a list of relevant competencies of intrapreneurial in the creative sector that can be adopted for the competency model of a fashion company. The initial competency model comprised 38 competency units that grouped into nine competency group, as shown in Figure 1.

The second stage is a preliminary study by interviews with several managers located in Bandung to obtain the competencies needed to increase intrapreneurship. This stage is needed to ensure that the competencies that are relevant to the intrapreneurship are valid and useful. The interviews were conducted on three managers, namely the Head of the Human Resources Development \& General Affairs Department (HRD \& GA), the Design \& Development Division Head, and the Head of the Department of Finance \& Accounting. The results of this interview will be used as input for designing the questionnaire. The two stages to identify relevant competencies also conducted in Wickramasinghe and De Zoyza (2009) and Aisha, Siswanto, and Sudirman (2016).

After identifying the relevant competencies, next is conduct a survey using questionnaires that contained the individual perceptions of how important and how often a specific competency for performing the job. The questionnaire was designed using a 5-point Likert scale to measure the level of importance and frequency from a competency unit. The general data requested in the questionnaire is the job level. 


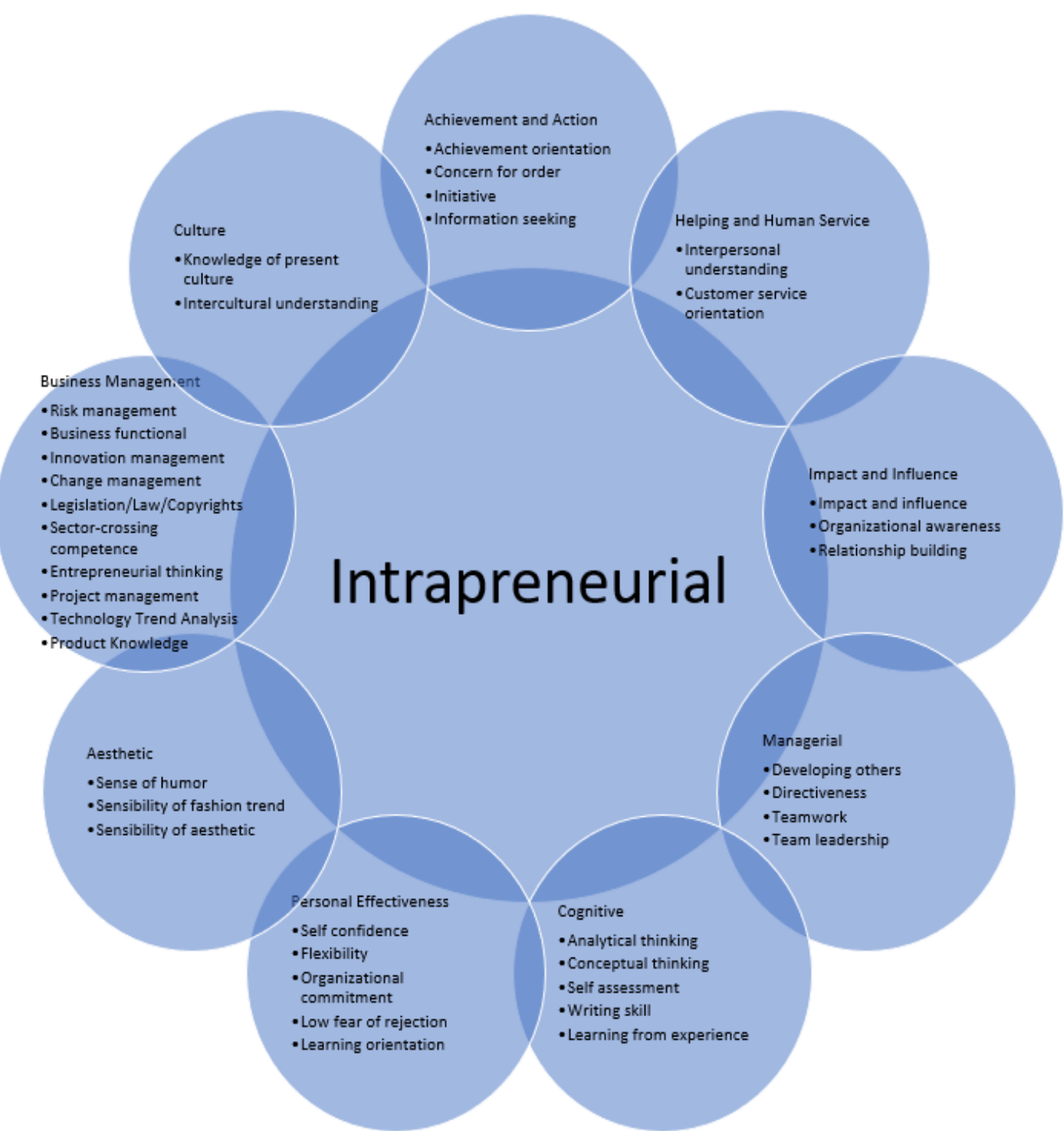

Figure 1: Proposed Intrapreneurial Competency Model

The results of the questionnaire will be processed through several statistical techniques using SPSS. To identify the gap competency based on importance and frequency level, the Wilcoxon signed rank-sum test, and importance-performance analysis (IPA) was conducted separately between the managerial level and non-managerial level. Mann-Whitney U-test was conducted to see differences in the need for intrapreneurial competencies for non-managerial and managerial positions.

\section{RESULTS AND DISCUSSIONS}

Based on the literature study obtained a competency model consisting of 9 competency groups and 38 competency units. This competency model becomes the basis for conducting interviews with some managers to obtain the competencies needed to improve intrapreneurship. The interview results show that the company needs 38 competency units in the conceptual model of increasing intrapreneurship, as shown in Table 2.

Table 2: Result of Preliminary Study

\begin{tabular}{lllll}
\hline \multirow{2}{*}{ Competency Unit } & \multicolumn{2}{l}{ Interview Result } & \multirow{2}{*}{ Competency used } \\
\cline { 2 - 5 } & HRD & Finance & Design & \\
\hline Achievement orientation & $\mathrm{V}$ & $\mathrm{V}$ & $\mathrm{V}$ & $\mathrm{V}$ \\
\hline Concern for order & $\mathrm{V}$ & $\mathrm{V}$ & $\mathrm{V}$ & $\mathrm{V}$ \\
\hline Initiative & $\mathrm{V}$ & $\mathrm{V}$ & $\mathrm{V}$ & $\mathrm{V}$ \\
\hline Information seeking & $\mathrm{V}$ & $\mathrm{V}$ & $\mathrm{V}$ & $\mathrm{V}$ \\
\hline Interpersonal understanding & $\mathrm{V}$ & $\mathrm{V}$ & $\mathrm{V}$ & $\mathrm{V}$ \\
\hline Customer service orientation & $\mathrm{V}$ & $\mathrm{V}$ & $\mathrm{V}$ & $\mathrm{V}$ \\
\hline Impact and influence & $\mathrm{V}$ & $\mathrm{V}$ & $\mathrm{V}$ & $\mathrm{V}$ \\
\hline Organizational awareness & $\mathrm{V}$ & $\mathrm{V}$ & $\mathrm{V}$ & $\mathrm{V}$ \\
\hline
\end{tabular}




\begin{tabular}{|c|c|c|c|c|}
\hline \multirow{2}{*}{ Competency Unit } & \multicolumn{3}{|c|}{ Interview Result } & \multirow{2}{*}{ Competency used } \\
\hline & HRD & Finance & Design & \\
\hline Relationship building & $\mathrm{v}$ & $\mathrm{v}$ & $\mathrm{v}$ & $\mathrm{v}$ \\
\hline Developing others & $\mathrm{v}$ & $\mathrm{v}$ & $\mathrm{v}$ & $\mathrm{v}$ \\
\hline Directiveness & $\mathrm{v}$ & $\mathrm{v}$ & $\mathrm{v}$ & $\mathrm{v}$ \\
\hline Teamwork & $\mathrm{v}$ & $\mathrm{v}$ & $\mathrm{v}$ & $\mathrm{v}$ \\
\hline Team leadership & $\mathrm{v}$ & $\mathrm{v}$ & $\mathrm{v}$ & $\mathrm{v}$ \\
\hline Analytical thinking & $\mathrm{v}$ & $\mathrm{v}$ & $\mathrm{v}$ & $\mathrm{v}$ \\
\hline Conceptual thinking & $\mathrm{v}$ & $\mathrm{v}$ & $\mathrm{v}$ & $\mathrm{v}$ \\
\hline Self-assessment & $\mathrm{v}$ & $\mathrm{v}$ & $\mathrm{v}$ & $\mathrm{v}$ \\
\hline Writing skill & $\mathrm{v}$ & $\mathrm{v}$ & $\mathrm{v}$ & $\mathrm{v}$ \\
\hline Learning from experience & $\mathrm{v}$ & $\mathrm{v}$ & $\mathrm{v}$ & $\mathrm{v}$ \\
\hline Self-confidence & $\mathrm{v}$ & $\mathrm{v}$ & $\mathrm{v}$ & $\mathrm{v}$ \\
\hline Flexibility & $\mathrm{v}$ & $\mathrm{v}$ & $\mathrm{v}$ & $\mathrm{v}$ \\
\hline Organizational Commitment & $\mathrm{v}$ & $\mathrm{v}$ & $\mathrm{v}$ & $\mathrm{v}$ \\
\hline Low fear of rejection & $\mathrm{v}$ & $\mathrm{v}$ & $\mathrm{v}$ & $\mathrm{v}$ \\
\hline Learning orientation & $\mathrm{v}$ & $\mathrm{v}$ & $\mathrm{v}$ & $\mathrm{v}$ \\
\hline Sense of humor & $\mathrm{v}$ & $\mathrm{v}$ & & $\mathrm{v}$ \\
\hline The sensibility of fashion trend & $\mathrm{v}$ & $\mathrm{v}$ & & $\mathrm{v}$ \\
\hline Sensibility of aesthetics & $\mathrm{v}$ & $\mathrm{v}$ & & $\mathrm{v}$ \\
\hline Risk management & $\mathrm{v}$ & $\mathrm{v}$ & $\mathrm{v}$ & $\mathrm{v}$ \\
\hline Business functional & $\mathrm{v}$ & $\mathrm{v}$ & $\mathrm{v}$ & $\mathrm{v}$ \\
\hline Innovation management & $\mathrm{v}$ & $\mathrm{v}$ & $\mathrm{v}$ & $\mathrm{v}$ \\
\hline Change management & $\mathrm{v}$ & $\mathrm{v}$ & $\mathrm{v}$ & $\mathrm{v}$ \\
\hline Legislation/law/IP and copyrights & $\mathrm{v}$ & $\mathrm{v}$ & $\mathrm{v}$ & $\mathrm{v}$ \\
\hline Sector-crossing competence & $\mathrm{v}$ & $\mathrm{v}$ & & $\mathrm{v}$ \\
\hline Entrepreneurial thinking & $\mathrm{v}$ & $\mathrm{v}$ & & $\mathrm{v}$ \\
\hline Project management & $\mathrm{v}$ & $\mathrm{v}$ & $\mathrm{v}$ & $\mathrm{v}$ \\
\hline Technology trend analysis & $\mathrm{v}$ & $\mathrm{v}$ & $\mathrm{v}$ & $\mathrm{v}$ \\
\hline Product knowledge & $\mathrm{v}$ & $\mathrm{v}$ & $\mathrm{v}$ & $\mathrm{v}$ \\
\hline Knowledge of Present culture & $\mathrm{v}$ & $\mathrm{v}$ & $\mathrm{v}$ & $\mathrm{v}$ \\
\hline Intercultural understanding & $\mathrm{v}$ & $\mathrm{v}$ & & $\mathrm{v}$ \\
\hline
\end{tabular}

The designed questionnaire consists of 38 statement items that represent each competency unit. Before processing data at the level of importance and frequency of competence, the validity and reliability of the questionnaire were tested. A validity test was carried out using the Spearman correlation test and obtained results that all statements on the questionnaire were declared valid. Reliability testing was carried out using the Cronbach alpha coefficient, obtained an alpha coefficient of 0.943 for importance questionnaire and 0.969 for frequency questionnaire. Thus, the questionnaire was declared reliable.

Table 3 summarizes the result of Wilcoxson signed rank-sum test, to identify the competency gap in the non-managerial level based on the level of importance and frequency of a competency unit. 16 competency units have a significant difference between the level of importance and frequency of use of competencies in non-managerial level employees. The competency units are information seeking, customer service orientation, organizational awareness, developing others, directiveness, team leadership, writing skills, self-confidence, organizational commitment, and sense of humor, the sensibility of aesthetics, innovation management, sector-crossing competence, entrepreneurial thinking, project management, and technology trend analysis.

Table 3: Result of Wilcoxson Signed Sum Rank Test for Non-Managerial Level

\begin{tabular}{llll}
\hline Competency Units & Code & Z & P-Value \\
\hline Achievement orientation & P1 & $-1,743$ & 0,081 \\
\hline Concern for order & P2 & $-1,544$ & 0,123 \\
\hline Initiative & P3 & $-1,282$ & 0,200 \\
\hline Information seeking & P4 & $-2,441$ & $0,015^{*}$ \\
\hline Interpersonal understanding & P5 & $-0,907$ & 0,365 \\
\hline Customer service orientation & P6 & $-3,150$ & $0,002^{*}$ \\
\hline Impact and influence & P7 & $-0,597$ & 0,550 \\
\hline Organizational awareness & P8 & $-2,496$ & $0,013^{*}$ \\
\hline Relationship building & P9 & $-1,357$ & 0,175 \\
\hline Developing others & P10 & $-3,007$ & $0,003^{*}$ \\
\hline Directiveness & P11 & $-2,719$ & $0,007^{*}$
\end{tabular}




\begin{tabular}{llll}
\hline Competency Units & Code & Z & P-Value \\
\hline Teamwork & $\mathrm{P} 12$ & $-0,383$ & 0,702 \\
\hline Team leadership & $\mathrm{P} 13$ & $-3,802$ & $0,000^{*}$ \\
\hline Analytical thinking & $\mathrm{P} 14$ & $-1,457$ & 0,145 \\
\hline Conceptual thinking & $\mathrm{P} 15$ & $-1,048$ & 0,295 \\
\hline Self assessment & $\mathrm{P} 16$ & $-0,347$ & 0,729 \\
\hline Writing skill & $\mathrm{P} 17$ & $-2,265$ & $0,024^{*}$ \\
\hline Learning from experience & $\mathrm{P} 18$ & $-1,316$ & 0,188 \\
\hline Self confidence & $\mathrm{P} 19$ & $-4,630$ & $0,000^{*}$ \\
\hline Flexibility & $\mathrm{P} 20$ & $-0,478$ & 0,633 \\
\hline Organizational Commitment & $\mathrm{P} 21$ & $-2,530$ & $0,011^{*}$ \\
\hline Low fear of rejection & $\mathrm{P} 22$ & $-1,580$ & 0,114 \\
\hline Learning orientation & $\mathrm{P} 23$ & $-0,209$ & 0,835 \\
\hline Sense of humor & $\mathrm{P} 24$ & $-4,806$ & $0,000^{*}$ \\
\hline Sensibility of fashion trend & $\mathrm{P} 25$ & $-1,210$ & 0,226 \\
\hline Sensibility of aesthetics & $\mathrm{P} 26$ & $-2,959$ & $0,003^{*}$ \\
\hline Risk management & $\mathrm{P} 27$ & $-1,014$ & 0,311 \\
\hline Business functional & $\mathrm{P} 28$ & $-0,026$ & 0,979 \\
\hline Innovation management & $\mathrm{P} 29$ & $-2,028$ & $0,043^{*}$ \\
\hline Change management & $\mathrm{P} 30$ & $-1,166$ & 0,244 \\
\hline Legislation/law/IP and copyrights & $\mathrm{P} 31$ & $-1,077$ & 0,281 \\
\hline Sector-crossing competence & $\mathrm{P} 32$ & $-2,435$ & $0,015^{*}$ \\
\hline Entrepreneurial thinking & $\mathrm{P} 33$ & $-3,481$ & $0,001^{*}$ \\
\hline Project management & $\mathrm{P} 34$ & $-3,834$ & $0,000^{*}$ \\
\hline Technology trend analysis & $\mathrm{P} 35$ & $-5,006$ & $0,000^{*}$ \\
\hline Product knowledge & $\mathrm{P} 36$ & $-1,291$ & 0,197 \\
\hline Knowledge of Present Culture & $\mathrm{P} 37$ & $-0,847$ & 0,397 \\
\hline Intercultural Understanding & $\mathrm{P} 38$ & $-0,761$ & 0,447 \\
\hline
\end{tabular}

*significance at level 0.05 (p-value $<0.05$ )

The results of the Wilcoxon test only show whether the difference between importance and frequency is significant or not. However, this test does not indicate the direction of the differences that occur. Basically, the ideal situation will be achieved when the importance level of competency in doing a job is the same as the level of frequency of use of these competencies in completing a job. If the level of interest to competencies is high, the frequency of using these competencies must also be high, likewise the opposite. Therefore, for competency units that differ significantly based on the Wilcoxon test results, it must be known whether the difference is caused by higher importance values and lower frequencies or vice versa. In this case, the importance-performance analysis method is used. The mapping results of the 16 competency units that significance difference on the importance-frequency diagram can be seen in Figure 2 .

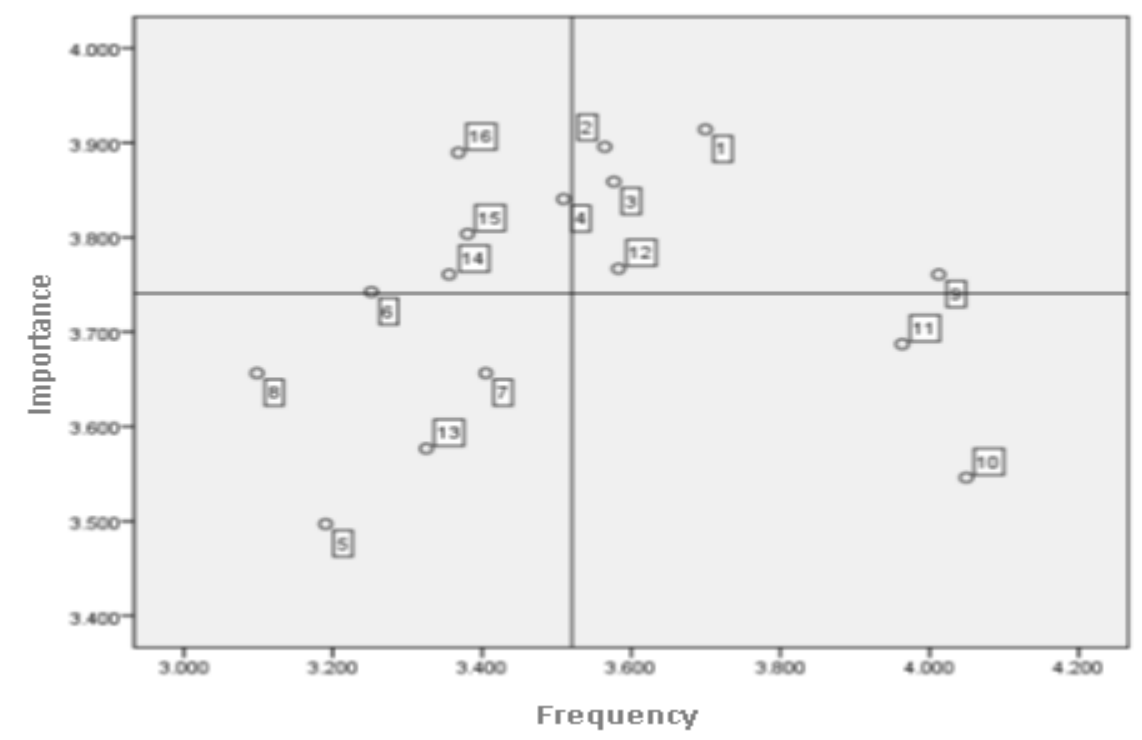

Figure 2: Importance-Frequency Diagram of Non-Managerial Level 
Based on the results of the importance-frequency diagram in Figure 2, five competency units that have a significant difference between the level of importance and frequency of their use and become a top priority to be resolved in nonmanagerial positions. These competencies are in the high-importance but low-frequency quadrant, namely developing others, team leadership, entrepreneurial thinking, project management, and technology trend analysis. These results indicate the low competence of employees related to the identification of new opportunities. Thus, the gap that occurs in entrepreneurial thinking competencies is indeed a top priority that must be developed. The choice of entrepreneurial thinking is a top priority in non-managerial positions, where there are no gaps in managerial positions in this unit of competency, indicating that this unit of competency is also needed at all levels of the jobs, including non-managerial positions. The developing other competency unit and leadership team which have only been considered important at the managerial level, also shows that the non-managerial level also needs these two competency units. Project management competency is also a top priority to be developed. This competency is considered important because in carrying out activities related to intrapreneurship, it takes planning to implement an efficient project so that the project designed can support the objectives of the company. Technology trend analysis competencies are also assessed as being a priority because this competency is very supportive in activities related to intrapreneurship. Knowledge and ability to use new technology is needed in creating new products in the company.

Meanwhile, the result of Wilcoxson signed rank-sum test, to identify the competency gap in the managerial level based on the level of importance and frequency of a competency unit, can be seen in Table 4 . The results obtained indicate that six competency units in managerial positions have a significant difference between the importance and frequency of their use. These competency units are initiatives, information seeking, customer service orientation, developing others, leadership teams, and change management.

Table 4: Result of Wilcoxson Signed Sum Rank Test for Managerial Level

\begin{tabular}{llll}
\hline Competency Units & Code & Z & P-Value \\
\hline Achievement orientation & P1 & $-1,754$ & 0,079 \\
\hline Concern for order & P2 & $-0,232$ & 0,817 \\
\hline Initiative & P3 & $-2,087$ & $0,037^{*}$ \\
\hline Information seeking & P4 & $-2,218$ & $0,027^{*}$ \\
\hline Interpersonal understanding & P5 & $-0,270$ & 0,787 \\
\hline Customer service orientation & P6 & $-2,056$ & $0,040^{*}$ \\
\hline Impact and influence & P7 & -1494 & 0,135 \\
\hline Organizational awareness & P8 & $-1,964$ & 0,050 \\
\hline Relationship building & P9 & $-1,594$ & 0,111 \\
\hline Developing others & P10 & $-2,275$ & $0,023^{*}$ \\
\hline Directiveness & P11 & $-0,342$ & 0,732 \\
\hline Teamwork & P12 & $-0,250$ & 0,802 \\
\hline Team leadership & P13 & $-2,829$ & $0,005^{*}$ \\
\hline Analytical thinking & P14 & $-0,425$ & 0,671 \\
\hline Conceptual thinking & P15 & $-0,166$ & 0,868 \\
\hline Self-assessment & P16 & -1647 & 0,100 \\
\hline Writing skill & P17 & $-1,099$ & 0,272 \\
\hline Learning from experience & P18 & $-0,752$ & 0,452 \\
\hline Self-confidence & P19 & $-0,673$ & 0,501 \\
\hline Flexibility & P20 & $-0,171$ & 0,864 \\
\hline Organizational Commitment & P21 & $-0,042$ & 0,967 \\
\hline Low fear of rejection & P22 & $-0,576$ & 0,565 \\
\hline Learning orientation & P23 & $-0,408$ & 0,683 \\
\hline Sense of humor & P24 & $-1,165$ & 0,244 \\
\hline Sensibility of fashion trend & P25 & $-1,380$ & 0,167 \\
\hline Sensibility of aesthetics & P26 & $-0,171$ & 0,864 \\
\hline Risk management & P27 & $-0,673$ & 0,501 \\
\hline Business functional & P28 & -1843 & 0,065 \\
\hline Innovation management & P29 & $-0,346$ & 0,730 \\
\hline Change management & P30 & $-2,805$ & $0,005^{*}$ \\
\hline Legislation/law/IP and copyrights & P31 & $-0,194$ & 0,846 \\
\hline Sector-crossing competence & P32 & $-1,731$ & 0,084 \\
\hline Entrepreneurial thinking & P33 & $-0,114$ & 0,909 \\
\hline Project management & P34 & $-0,390$ & 0,696 \\
\hline Technology trend analysis & P35 & $-1,254$ & 0,210 \\
\hline Product knowledge & P36 & $-1,096$ & 0,273 \\
\hline & & & \\
\hline
\end{tabular}




\begin{tabular}{llll}
\hline Competency Units & Code & Z & P-Value \\
\hline Knowledge of Present Culture & P37 & $-0,224$ & 0,823 \\
\hline Intercultural Understanding & P38 & $-0,344$ & 0,731 \\
\hline
\end{tabular}

*significance at level 0.05 (p-value < 0.05)

Based on Table 3 and Table 4, there are four competency units that have significant differences between the level of importance and frequency of use of these competencies at managerial and non-managerial level workers. The four competency units include information seeking, customer service orientation, developing others, and leadership teams. These results indicate that the four competencies need to be evaluated regarding the level of individual mastery and the demand for mastery needs in the positions assigned, to design appropriate training programs at managerial and nonmanagerial levels. In addition, this significant difference also indicates the need for evaluation and improvement in job analysis, because it indicates a difference between the perception of importance and the frequency of use of competencies. Just as in processing data at a non-managerial level, to determine the priority of competency development needs, the importance-frequency diagram was mapped. Fig. 3 shows the results of the importance-frequency diagram of the managerial level.

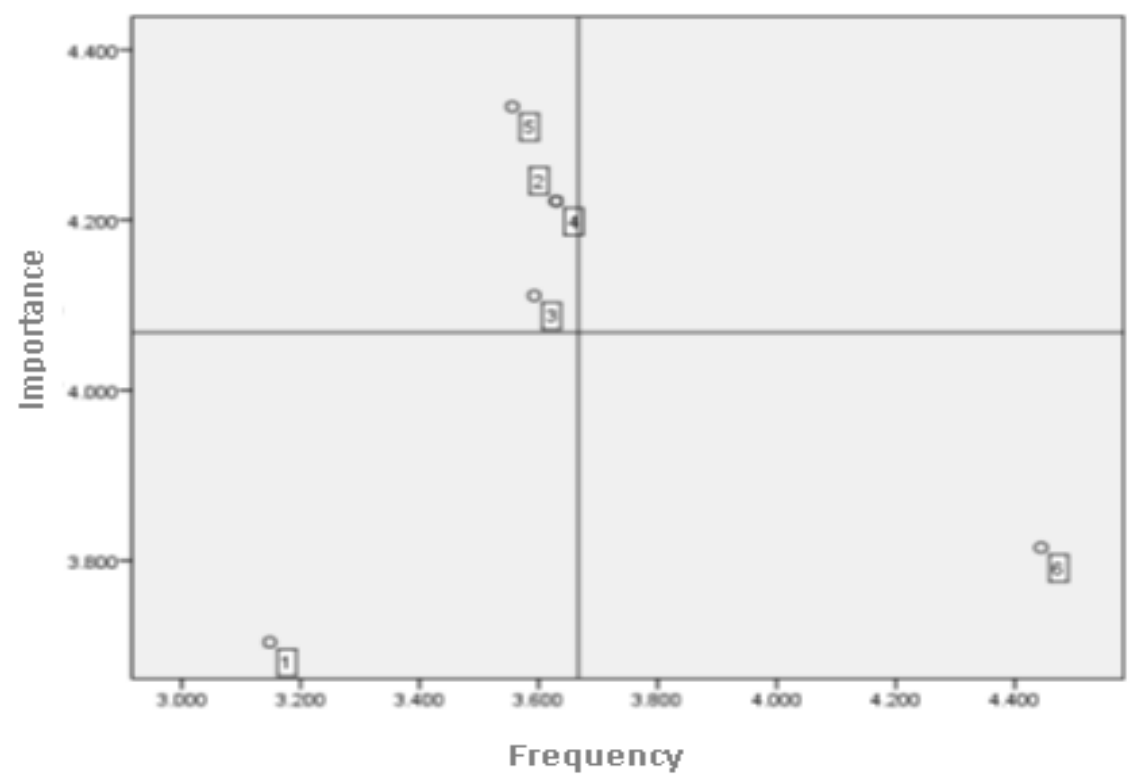

Figure 3: Importance-Frequency Diagram of Managerial Level

Based on Figure 3, there are four competency units which are the top priorities, namely information seeking, customer service orientation, developing others, and leadership teams. The developing others and team leadership competency units are competencies that are highly needed by managerial levels, so the lower frequency of use is a top priority to be developed. Customer service orientation competencies are also competencies needed by managerial levels in helping and meeting customer needs. This competency is considered to be the priority because in conducting intrapreneurship activities an orientation will be needed to fulfill customer needs. Information seeking competencies are competencies that can support other competencies. This competency can be the basis for conducting intrapreneurship activities, namely as an initial stage in seeking information such as information on opportunities that can be done in expanding markets.

Several things cause the gap between the level of importance and the frequency of using competencies in nonmanagerial and managerial positions. There are three causes of a low frequency of use in competencies that are considered necessary, among others (1) company employees do not have sufficient capacity for related competency units (incompetent). This cause can be overcome by developing through training, improving recruitment/selection, or rotating employees; (2) lack of encouragement from within the employee to use the competencies that exist in him. This can happen because of low motivation, fear, or feeling lazy. This cause is quite difficult to overcome because it speaks of factors that come from within each; (3) different job demands from the job description. For example, the writing skill competency unit that is considered important for a secretary in doing work has a relatively low frequency of use. This is caused by the daily activities of the secretary who is not following what should be done like other demands for making drinks and so on. This cause can be overcome by conducting further research to see the workload of employees. Mann Whitney U-test used to identify the differences in the importance level of competencies between non-managerial and managerial positions. Based on the test, it was found that nine competencies were significantly different in the importance level between non-managerial and managerial positions, as shown in Table 5. 
Table 5: Result of Mann-Whitney U-Test

\begin{tabular}{|c|c|c|c|c|c|}
\hline Competencies & Imp. $\mathbf{N M}^{\mathrm{a}}$ & Imp. $\mathbf{M}^{\mathrm{b}}$ & z-values & p-values & Distinctive Competencies \\
\hline Achievement orientation & 4.08 & 4.37 & -2.266 & 0.023 & $\mathrm{~V}$ \\
\hline Concern for order & 4.07 & 4.33 & -2.569 & 0.010 & $\mathrm{v}$ \\
\hline Initiative & 3.33 & 3.70 & -1.883 & 0.060 & \\
\hline Information seeking & 3.91 & 4.22 & -2.053 & 0.040 & $\mathrm{~V}$ \\
\hline Interpersonal understanding & 3.93 & 3.93 & -0.178 & 0.859 & \\
\hline Customer service orientation & 3.90 & 4.11 & -1.590 & 0.112 & \\
\hline Impact and influence & 3.44 & 3.81 & -1.821 & 0.069 & \\
\hline Organizational awareness & 3.86 & 4.11 & -1.776 & 0.076 & \\
\hline Relationship building & 4.07 & 4.48 & -2.916 & 0.004 & $\mathrm{v}$ \\
\hline Developing others & 3.84 & 4.22 & -2.432 & 0.015 & $\mathrm{~V}$ \\
\hline Directiveness & 3.50 & 3.81 & -1.882 & 0.060 & \\
\hline Teamwork & 3.98 & 4.37 & -2.724 & 0.006 & $\mathrm{~V}$ \\
\hline Team leadership & 3.74 & 4.33 & -3.303 & 0.001 & $\mathrm{v}$ \\
\hline Analytical thinking & 3.18 & 3.70 & -2.304 & 0.021 & $\mathrm{v}$ \\
\hline Conceptual thinking & 3.63 & 3.67 & -0.392 & 0.695 & \\
\hline Self-assessment & 3.88 & 3.74 & -0.899 & 0.369 & \\
\hline Writing skill & 3.66 & 3.89 & -1.592 & 0.111 & \\
\hline Learning from experience & 3.70 & 3.67 & -0.150 & 0.881 & \\
\hline Self-confidence & 3.66 & 3.44 & -0.516 & 0.606 & \\
\hline Flexibility & 3.92 & 4.11 & -1.214 & 0.225 & \\
\hline Organizational Commitment & 3.76 & 4.11 & -1.870 & 0.061 & \\
\hline Low fear of rejection & 3.55 & 3.59 & -0.414 & 0.679 & \\
\hline Learning orientation & 3.80 & 4.00 & -1.369 & 0.171 & \\
\hline Sense of humor & 3.55 & 4.04 & -2.359 & 0.018 & $\mathrm{~V}$ \\
\hline The sensibility of fashion trend & 3.66 & 3.74 & -0.243 & 0.808 & \\
\hline Sensibility of aesthetics & 3.69 & 4.00 & -1.572 & 0.116 & \\
\hline Risk management & 3.92 & 3.85 & -0.141 & 0.888 & \\
\hline Business functional & 3.53 & 3.52 & -0.053 & 0.958 & \\
\hline Innovation management & 3.77 & 3.41 & -1.574 & 0.115 & \\
\hline Change management & 3.77 & 3.81 & -0.069 & 0.945 & \\
\hline Legislation/law/IP and copyrights & 3.51 & 3.26 & -1.124 & 0.261 & \\
\hline Sector-crossing competence & 3.58 & 3.56 & -0.191 & 0.848 & \\
\hline Entrepreneurial thinking & 3.76 & 3.41 & -1.616 & 0.106 & \\
\hline Project management & 3.80 & 3.70 & -0.057 & 0.955 & \\
\hline Technology trend analysis & 3.89 & 3.74 & -0.477 & 0.634 & \\
\hline Product knowledge & 3.81 & 4.04 & -1.298 & 0.194 & \\
\hline Knowledge of Present culture & 3.60 & 3.59 & -0.361 & 0.718 & \\
\hline Intercultural understanding & 3.71 & 3.78 & -0.168 & 0.866 & \\
\hline
\end{tabular}

${ }^{\mathrm{a}}$ Importance average values of non-managerial; ${ }^{\mathrm{b}}$ Importance average values of managerial; ${ }^{\mathrm{c}} \mathrm{z}$-values for Mann-Whitney U Test

According to Table 5, there is a difference in importance mean level for the nine distinctive competencies between nonmanagerial and managerial positions. Those nine distinctive competencies, which are achievement orientation, relationship building, concern for orders, developing others, information seeking, teamwork, analytical thinking, team leadership, and sense of humor, have a higher level of importance in managerial positions. Thus, it can be concluded that the managerial positions need these nine distinctive competencies more in doing their job. The three of these distinctive competencies are included in the group of managerial competence, namely developing others, teamwork, and leadership teams, so it can be concluded that these three competency units are indeed needed in managerial positions.

Achievement orientation is also related to innovation and entrepreneurship. One of the behavioral indicators of this competence is the ability to try something new, achieve challenging targets, such as trying new products and still take into account the risks. In increasing intrapreneurship, the managerial level as an activator in generating innovation requires this competence. Concern for order, which is the ability to reduce the uncertainty that is closely related to monitoring is also really needed by the managerial level in ensuring the journey of a job or information, especially in supervising their subordinates. Information seeking competence possessed by managerial levels are also very appropriate, namely about finding information in making decisions. One indicator is to search potential for opportunities or various kinds of information that might be needed in the future (Spencer and Spencer, 1993). 
Relationship building is the ability to build and maintain relationships with others (Spencer and Spencer, 1993). Compared to non-managerial levels, the managerial level will be needed more than their subordinates because they have to build a closer and warmer relationship, to broaden the organization network. Analytical thinking at the managerial level is essential because of its usefulness in evaluating the existing products and services or in the planning process.

The last competence, the sense of humor, is considered more important at the managerial level. This competency is closely related to creating a conducive atmosphere to give a comfortable working environment. In general, managerial levels will have subordinates. Under pressure, the condition will hinder the innovation generation process. For that, this competency becomes essential to push the employee to generate new ideas. Thus, it can be concluded that all of the above competencies are considered appropriate if the level of importance is higher at the managerial level.

Besides, Table 5 also shows that entrepreneurial thinking and innovation management which are the primary competencies of intrapreneurship do not differ at an important level at the non-managerial and managerial positions. This similarity shows that all levels of the organization need these competencies. Employees from all levels are expected to contribute to innovation related to both products and processes. Referring to Aisha, et al. (2019), one of the keys to success in the creative industry is creativity and innovation at the individual and group level. Both of these are sourced from creative human resources including workers and managers in the company. Therefore, it is important to empower the company's human resources in encouraging the innovation process.

Based on the results obtained, differences in competency needs between non-managerial and managerial positions will assist in identifying competency development needs for employees who will be promoted from non-managerial to managerial positions. This competency development can be done using training. However, for some competency units which are classified as hidden competencies, those that are at the bottom of the iceberg (self-concept, trait, and motive) will tend to be more difficult to develop or train because they require a longer time. Several of the nine competency units categorized as hidden competencies are achievement orientation, concern for order, information seeking, and sense of humor. Thus, to fulfill the needs of those competencies, it is required to recruit employees who have this competence already.

\section{CONCLUSION}

This study produced an intrapreneurial competency model in the fashion industry consists of 38 competency units grouped into nine competency groups. These 38 competency units are needed to increase intrapreneurship in fashion companies. From these 38 competency units, nine distinctive competency units were significantly different in importance between non-managerial and managerial positions:(1) achievement orientation;(2) concern for order;(3) relationship building; (4) information seeking;(5) teamwork;(6) developing others; (7) team leadership;(8) analytical thinking;(9) sense of humor. These competency units have a higher level of importance in managerial positions.

This study also produced competency priorities that need to be developed at managerial and non-managerial levels. At the managerial level, the priority of developing competencies is related to four competency units, namely information seeking, customer service orientation, developing others, and leadership teams. While at the non-managerial level, the priority of developing competencies is related to five competency units, including developing others, team leadership, entrepreneurial thinking, project management, and technology trend analysis. These results indicate that different job levels require differences in competency development priorities.

Although the study showed essential findings in the intrapreneurial context of the fashion subsector, this study had several limitations. This study conduct in a case study of a fashion company, so different results can be found if gathering more data in another fashion company. For this reason, further research can be carried out for similar research from the fashion industry in a separate location. Also, to get a more generic model of intrapreneurial competencies in creative industries, research can be done in other creative industries subsectors. Another recommendation, further research can be conducted to identify competency-based training needs and design training programs that are in line with the position level positions.

\section{ACKNOWLEDGEMENT}

This research was funded by a "Higher Education Applied Research Grant" from the Ministry of Research, Technology and Higher Education, and was supported by the Industrial Management Research Group (Bandung Institute of Technology).

\section{REFERENCES}

1. Aisha, A. N., Siswanto, J., and Sudirman I. (2016, December). Competencies Model for Entrepreneur Development in Software Industries. In Proceedings of Industrial Engineering and Engineering Management, 184-188. https://doi.org/10.1109/IEEM.2016.7797861

2. Aisha, A. N., Sudirman, I., Siswanto, J., and Andriani, M. (2019). A Competency Model for SMEs in the Creative Economy. International Journal of Business, 24(4), 369-392.

3. Bosma, N., Wennekers, S., and Stam, E. (2010). Intrapreneurship: An international study. EIM Business and Policy Research. 
4. Cadar, O., and Badulescu, D. (2015). Entrepreneur, entrepreneurship and intrapreneurship. A literature review. The Annals of The University of Oradea, Economic Sciences, 2(24), 658-664.

5. Chouhan, V. S., and Srivastava, S. (2014). Understanding competencies and competency modelling-A literature survey. IOSR Journal of Business and Management, 16(1), 14-22. https://doi.org/10.9790/487X16111422

6. Dai, G., and Liang, K. (2012). Competency modelling research and practice in China: a literature review. Journal of Chinese Human Resources Management, 3(1), 49-66. https://doi.org/10.1108/20408001211220566

7. Dubois, D. D., and Rothwell, W. J. (2004). Competency-Based Human Resource Management. Davies-Black Publishing, California.

8. Hair, J.F., Black, W. C., Babin, B. J., and Anderson, R. E. (2010). Multivariate Data Analysis. Pearson Prentice Hall, New Jersey.

9. Hu, M. L. M. (2010). Developing a core competency model of innovative culinary development. International Journal of Hospitality Management, 29(4), 582-590. https://doi.org/10.1016/j.ijhm.2009.10.024

10. Indonesia Creative Economy Agency (2017). Profil Usaha/Perusahaan 16 Subsektor Ekonomi Kreatif Berdasarkan Sensus Ekonomi 2016 (katalog: 9102060). Badan Pusat Statistik, Jakarta. Available: http://www.bekraf.go.id. [Accessed March, 2018].

11. Maier, V. and Zenovia, C.P. (2011). Entrepreneurship versus Intrapreneurship. Review of International Comparative Management. 12(5), 971-976

12. Mietzner, D., and Kamprath, M. (2013). A competence portfolio for professionals in the creative industries. Creativity and Innovation Management, 22(3), 280-294. https://doi.org/10.1111/caim.12026

13. Müller, K., Rammer, C., and Trüby, J. (2009). The role of creative industries in industrial innovation. Innovation, 11(2), 148-168. https://doi.org/10.5172/impp.11.2.148

14. Rathna, K. G., and Vijaya, T. G. (2009). Competencies of entrepreneurs and intrapreneurs: A comparative study. South Asian Journal of Management, 16(2), 28.

15. Siswanto, J. (2013). Implementasi Sistem Manajemen Sumber Daya Manusia Berbasis Kompetensi Terpadu: Strategi Pengembangan Organisasi Pendekatan Sistem. Penerbit ITB, Bandung.

16. Spencer L. M., and Spencer, S. M. (1993). Competence at Work: Models for Superior Performance. John Wiley \& Sons, New York.

17. Vargas-Halabí, T., Mora-Esquivel, R., and Siles, B. (2017). Intrapreneurial competencies: development and validation of a measurement scale. European Journal of Management and Business Economics, 26(1), 86-111. https://doi.org/10.1108/EJMBE-07-2017-006

18. Wickramasinghe, V., and Zoyza, N. D. (2009). An assessment of managerial competency needs: Empirical evidence from a Sri Lankan telecommunication service provider. The International Journal of Human Resource Management, 20(12), 2547-2567. https://doi.org/10.1080/09585190903363854 